\section{Paul Jarvis, FRS, FRSE: plant ecologist who showed the link between forests and the atmosphere}

\section{Maurizio Mencuccini}

Paul Gordon Jarvis (born Tunbridge Wells 23/05/1935, died Aberfeldy 05/02/2013) was a widely known and well respected plant ecologist and micro-meteorologist, who pioneered the scientific analysis of the exchange of water and carbon dioxide between forests and the atmosphere, and laid the foundations for decades of studies on the interplay between forests and the climate system.

His father was a farmer in Hertfordshire, and a founder member of the Royal Air Force Regiment in World War II. He flew Sopwith Camels. Paul's mother had been a secretary to the geneticist Karl Pearson at University College, London. Paul showed an early academic talent and went to Oxford to read Botany at Oriel College, where he met his future wife Margaret. They went on to graduate studies at Sheffield, investigating the growth and regeneration of oaks and the limits to the distribution of other trees in the UK.

Thanks to two NATO scholarships, Margaret and Paul moved to the Institute of Plant Physiology in Uppsala (Sweden) at the end of their PhDs. Here, they became especially interested in the measurement and state of water in plants. Paul gained a second doctorate from Uppsala, while Margaret began working as scientific editor and translator, following the birth of their first son Eric.

Other alliances were forged when the couple moved to Australia in 1964, where Paul took up a position as permanent visiting scientist at CSIRO with Ralph Slatyer, an outstanding plant physiologist who later became Australia's first Chief Scientist.

$\square$ School of GeoSciences, University of Edinburgh, Crew Building, West Mains Road, EH9 3JN Edinburgh (UK)

\section{(a), Maurizio Mencuccini}

(m.mencuccini@ed.ac.uk)

Citation: Mencuccini M, 2013. Paul Jarvis, FRS, FRSE: plant ecologist who showed the link between forests and the atmosphere. iForest 6: 100-101 [online 2013-02-12] URL: http://www. sisef.it/iforest/contents/? id=ifor $0102-006$

Communicated by: Marco Borghetti
However, much of Paul's career developed in the UK, first at Aberdeen from 1966 to 1975, and then at Edinburgh where he became Professor of Forestry and Natural Resources in 1975 . He remained there until he retired in 2001. During those 35 years, Paul's career developed enormously, with ground-breaking studies on several aspects of the environmental physiology of forests, measuring the behaviour of stomata under changing environmental conditions, the penetration of light into forest canopies, water transport in trees and the micro-meteorological measurement of the fluxes of water vapour and carbon dioxide above the canopy. All these studies were characterised by a very innovative combination of strongly physically-grounded principles, intelligent construction of novel pieces of equipment and a deep knowledge of the fundamental physiology of trees. He developed one of the first process-based models of forest function, MAESTRO (later renamed MAESTRA by a female researcher), which has been employed for various purposes for at least three decades. With colleagues, he continued to develop the micro-meteorological method for the measurement of gas fluxes from forests, which eventually lead to the eddy covariance approach currently employed throughout the world.

Beyond these technological advancements, Paul wrote several fundamental reviews in plant environmental physiology, on topics ranging from the modelling of stomatal function, plant water relations and hydraulics, the scaling of water vapour and carbon dioxide fluxes from leaves to landscape and the effects of elevated $\mathrm{CO}_{2}$ on terrestrial vegetation. He took part in several high-profile international projects in different parts of the world, from the boreal forests of Canada to the Sahel in Africa and became a leading player in the EU-funded EUROFLUX project, the first multinational effort to tackle the problem of the response of terrestrial vegetation to climate change. In Canada he worked closely with Piers Sellers, an Edinburgh graduate who later became a NASA astronaut.

Paul was a founding member of the journal Plant, Cell and Environment, now one of the leading journals in plant science, and served on the Review Board of several other inter- national journals. He was President and Council member of the Society for Experimental Biology, various Research Council Boards, and he was a Commissioner of the Countryside Commission for Scotland; he was on several Scientific Steering Committees, including the IGBP and the John Muir Trust. He was elected Fellow of the Royal Society, Fellow of the Royal Society of Edinburgh, Fellow of the Royal Swedish Academy of Agriculture and Forestry, the Royal Science Society of Uppsala, the Institute of Chartered Foresters and the Institute of Biology and was awarded the Gregorius J. Mendel Medal by the Academy of Science of the Czech Republic for his services to science of that country.

Paul trained many $\mathrm{PhD}$ students and postdoctoral scientists in his laboratory, and helped innumerable students who came to visit him or whom he met at conferences, generously giving his time to any student who demonstrated a real interest and a willingness to learn.

He was vigorous and intense during scientific debates at conferences and seminars. He set the bar very high for his younger colleagues and students, demanding the highest standards of intellectual rigour. He leaves a huge scientific diaspora, extending across many countries of the world, setting similar high standards today.

He was a strong hill walker and marathon runner, and even on the university campus he would leave his colleagues behind on the journey from the Department to the refectory!

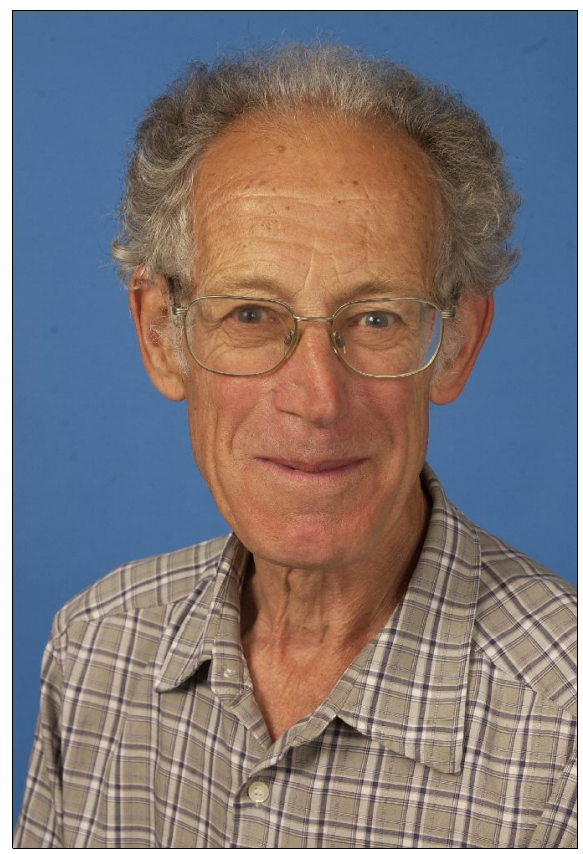

Fig. 1 - Paul Jarvis was associate editor in the editorial board of iForest - Biogeosciences and Forestry. 
After his retirement to Aberfeldy in 2001, he continued to be very active scientifically and became involved in the restoration of native woodlands on the over-browsed hills of Scotland. He became a Director of the Edinburgh Centre for Carbon Management, a small company concerned in part with the sequestration of carbon by forests to meet the goals of the Kyoto Protocol.

Paul was widely admired and universally respected in his field. His passion, intensity and love for science allowed him to break many barriers across countries, disciplines and scientific groups. $\mathrm{He}$ is fondly remembered by many colleagues around the world. Paul leaves his wife Margaret, son Eric and daughters Alice and Kathryn. 